\title{
FAKTOR KEDISIPLINAN BELAJAR PADA SISWA KELAS X SMK LARENDA BREBES
}

\author{
Ahmad Pujo Sugiarto ${ }^{1}$, Tri suyati ${ }^{2}$, Padmi Dhyah Yulianti ${ }^{3}$ \\ 1,2,3 Jurusan Bimbingan dan Konseling, Fakultas IImu Pendidikan \\ Universitas PGRI Semarang \\ Semarang, Indonesia \\ e-mail: pujoahmad86@gmail.com¹, suyatitri@gmail.com², \\ pdyuliantii@gmail.com ${ }^{3}$
}

\begin{abstract}
Abstrak
Penelitian ini dilatar belakangi oleh pentingnya kedisiplinan belajar siswa. Faktor kedisiplinan belajar siswa antara lain: Faktor internal adalah faktor yang ada dalam dirinya sendiri antara lain meliputi kesadaran diri, motivasi belajar, dan tidak mampu menyesuaikan diri dalam belajar. Sedangkan faktor eksternal adalah faktor dari luar yang meliputi faktor keluarga, lingkungan sekolah, teman sebaya dan masyarakat. Penelitian ini menggunakan pendekatan studi kasus yang dilakukan dengan cara mendeskripsikan atau memaparkan fakta-fakta atau data-data yang diperoleh dari sumber data. Data-data tersebut bersifat kualitatif karena tidak berupa angka, tetapi berupa kalimat-kalimat atau pernyataan-pernyataan yang berasal dari hasil metode observasi dan wawancara. Data-data tersebut selanjutnya dianalisis atau diuraikan untuk menemukan faktor kedisiplinan belajar siswa siswa. Berdasarkan data yang diperoleh dari subjek penelitian, menunjukan bahwa faktor kedisiplinan belajar siswa ada dua yaitu faktor intrinsik dan faktor ekstrinsik. Faktor intrinsik yaitu faktor yang berasal dari dirinya sendiri yaitu siswa yang malas, malas untuk belajar, tidak pernah mengerjakan PR atau tugas, malas untuk mencatat dan membaca buku pelajaran,kurangnya kesadaran untuk belajar, belum terbiasa dengan disiplin belajar. Kedua adalah faktor ekstrinsik merupakan faktor yang berasal dari luar individu berupa lingkungan keluarga, orangtua yang tidak pernah memberikan perhatian dan kasih sayang terhadap anak mengakibatkan anak menjadi tidak disiplin belajar, selain itu pendidikan orang tua juga mempengaruhi kedisiplinan belajar siswa, faktor lain adalah dari guru, guru yang galak dan cara mengajar yang membosankan menyebabkan siswa malas belajar, dan faktor terakhir yang mengakibatkan siswa tidak disiplin belajar karena faktor lingkungan seperti teman bergaul di rumah dan lingkungan sekolah.
\end{abstract}

Kata-kata kunci : Kedisiplinan Belajar, Siswa, Studi Kasus

\begin{abstract}
This research is motivated by the importance of student learning discipline. Factors of student learning discipline include: Internal factors are factors that exist in themselves include self-awareness, motivation to learn, and not being able to adjust to learning. While external factors are external factors which include family, school environment, peers and the community. This research uses a case study approach which is done by describing or describing facts or data obtained from data sources. The data is qualitative because it is not in the form of numbers, but in the form of sentences or statements derived from the results of observation and interview methods. These data are then analyzed or elaborated to find the factors of student learning discipline. Based on data obtained from research subjects, it shows that there are two factors for student learning discipline namely intrinsic factor and extrinsic factor. Intrinsic factor is a factor that originates from itself, namely students who are lazy, lazy to learn, never do homework or assignments, lazy to take notes and read textbooks, lack of awareness to learn, not accustomed to the discipline of learning. Second is the extrinsic factor is a factor that comes from outside the individual in the form of a family environment, parents who never give attention and affection towards children cause children to become undisciplined in learning, in addition to that parental education also affects student learning discipline, other factors are from the teacher, teachers who are fierce and boring teaching methods make students lazy to learn, and the last factor that causes
\end{abstract}


students to be undisciplined in learning because of environmental factors such as friends hanging out at home and school environment.

Keywords: Learning Discipline, Students, Case Studies

\section{Pendahuluan}

Pendidikan merupakan komponen untuk meningkatkan kualitas sumber daya manusia sesuai dengan tujuan pendidikan nasional. Adapun tujuan dari pendidikan yang termasuk dalam undang-undang No 20 Tahun 2003 tentang sistem pendidikan nasional adalah untuk mengembangkan kemampuan dan membentuk watak serta peradaban bangsa yang bermartabat dalam rangka mencerdaskan kehidungan bangsa yang bertujuan untuk perkembangan peserta didik agar menjadi manusia yang beriman dan bertaqwa kepada tuhan yang maha esa, berahlak mulia, sehat, berilmu, cakap, kreatif, mandiri dan menjadi warga negara yang demokratis serta tanggung jawab.

Berbicara masalah pendidikan salah satu aspeknya adalah disiplin siswa yang merupakan salah satu faktor yang mempengaruhi kegiatan siswa dalam proses belajar mengajar. Disiplin merupakan salah satu kunci keberhasilan dalam belajar. Upaya dalam mendisiplinkan siswa tidaklah mudah sebab membutuhkan kesadaran dari siswa. Perlu adanya pemberian dorongan dari orang terdekat. Begitu juga dalam proses belajar mengajar di kelas. Disiplin merupakan kunci utama dalam meraih kesuksesan. Karena Penyelenggaraan pengajaran menuntut adanya sikap disiplin siswa dalam mematuhi ketertiban untuk menyelesaikan dan mengerjakan tugas yang diberikan guru dalam memenuhi tugas belajar mengajar di sekolah. Menurut Haryono (2016) Keberhasilan siswa dalam studinya dipengaruhi oleh cara belajarnya. Siswayang memiliki cara belajar yang efektif memungkinkan untuk mencapai hasil atau prestasi yang lebih tinggi dari pada siswa yang tidak mempunyai cara belajar yang efektif. Untuk belajar secara efektif dan efisien diperlukan kesadaran berdisiplin dan motivasi belajar yang tinggi setiap siswa. Belajar secara efektif dan efisien dapat dilakukan oleh siswa yang berdisiplin. Siswa yang memiliki disiplin dalam belajarnya akan berusaha mengatur dan menggunakan strategi dan cara belajar yang tepat baginya. Jadi langkah pertama yang perlu dimiliki agar dapat belajar secara efektif dan efisien adalah kesadaran atas tanggung jawab pribadi dan keyakinan bahwa belajar adalah untuk kepentingan diri sendiri, dilakukan sendiri dan tidak menggantungkan nasib pada orang lain. Kedisiplinan siswa dan motivasi belajar merupakan dasar untuk mencapai prestasi yang baik, karena kedisiplinan dan motivasi merupakan dasar untuk memperoleh prestasi, terutama dalam mempelajari mata pelajaran ekonomi. Oleh karena itu kedisiplinan dan motivasi sangat berperan terhadap prestasi belajar siswa. Dengan sikap disiplin membuat siswa memiliki kecakapan menangani cara belajar yang baik, juga merupakan suatu proses menuju pembentukan watak yang baik. Pembentukan watak yang baik serta pretasi yang baik melalui beberapa Faktor dari dalam diri peserta didik antara lain, kecerdasan, bakat, minat, motivasi, disiplin diri dan kemandirian. Sedangkan faktor dari luar diri peserta didik dapat berupa lingkungan alam, kondisi sosial, ekonomi, lingkungan sekolah, guru, kurikulum dan sebagainya. Jadi dalam hal ini rendahnya prestasi belajar peserta didik dapat dapat disebabkan oleh berbagai faktor tersebut diatas. Dari faktorfaktor tersebut diatas, faktor dari dalam diri peserta didik merupakan faktor yang penting dalam menentukan keberhasilan belajar, sebab dalam proses belajar mengajar sasaran utamanya adalah peserta didik tersebut sebagai subyek belajar.

Pada dasarnya dalam diri setiap individu terdapat keunikannya masing-masing, misalnya dalam hal bakat, potensi, karakteristik, kelebihan dan kekurangan yang kesemuanya berbeda. Perbedaan kekurangan dan kelebihan individu yang sudah dimiliki sejak lahir, perlu disadari dan diterima sepenuhnya oleh individu yang bersangkutan. Realitanya tidak semua siswa mampu memaksimalkan kelebihan yang dimiliki, dan tidak jarang pula banyak siswa yang tidak mampu menerima kekukarangan dalam dirinya. Melalui Kedisiplinan terhadap 
kekurangan dan kelebihannya berfungsi sebagai pondasi awal untuk menentukan langkah berikutnya, berupa usaha pengembangan potensi yang dimiliki individu tersebut.

Disiplin adalah suatu kondisi yang tercipta dan terbentuk melalui proses dari serangkaian perilaku yang menunjukkan nilai-nilai ketaatan, kepatuhan, kesetiaan, keteraturan dan ketertiban. Disiplin akan membuat seseorang tahu dan dapat membedakan hal-hal apa yang seharusnya dilakukan, yang wajib dilakukan, yang boleh dilakukan, yang tak sepatutnya dilakukan (karena merupakan hal-hal yang dilarang). Bagi seorang yang berdisiplin, karena sudah menyatu dalam dirinya, maka sikap atau perbuatan yang dilakukan bukan lagi dirasakan sebagai beban, namun sebaliknya akan membebani dirinya apabila ia tidak berbuat disiplin. Nilai-nilai kepatuhan telah menjadi bagian dari perilaku dalam kehidupannya. Disiplin yang mantap pada hakikatnya akan tumbuh dan terpancar dari hasil kesadaran manusia. Sebaliknya, disiplin yang tidak bersumber dari kesadaran hati nurani akan menghasilkan disiplin yang lemah dan tidak akan bertahan lama, atau disiplin yang statis, tidak hidup (Soemarmo, Hal 20-21). Menurut Elly (2016) Disiplin merupakan suatu sikap ang menunjukkan kesediaan untuk menepati atau mematuhi ketentuan, tat tertib, nilai serta kaidah-kaidah yang berlaku. Disiplin mengandung asas taat, yaitu kemampuan untuk bersikap dan bertindak secara konsisten berdasar pada suatu nilai tertentu. Dalam proses belajar mengajar, kedisiplinan dapat menjadi alat yang bersifat preventif untuk mencegah dan menjaga hal-hal yang dapat mengganggu dan menghambat proses belajar. Untuk itu berbagai peratutan ikut diberlakukan di sekolah-sekolah untuk menegakkan tingkat kedisiplinan siswa. Menurut Johan (2014) Disiplin bagi peserta didik adalah hal yang rumit dipelajari sebab merupakan hal yang kompleks dan banyak kaitannya, yaitu terkait dengan pengetahuan, sikap dan perilaku. Masalah disiplin yang dibahas dalam penelitian ini adalah disiplin yang dilakukan oleh para peserta didik dalam kegiatan belajarnya baik di rumah maupun di sekolah. Menurut Rumia (2015) Anak-anak yang disiplin dalam belajar mempunyai tingkat kompetensi lebih tinggi dibandingkan dengan anak-anak yang tidak disiplin. Pengaruh disiplin terhadap prestasi belajar peserta didik menjadi faktor paling utama dalam keberhasilan penguasaan pelajaran di sekolah. Penerapan disiplin ini tidak hanya dilihat dari disiplin dalam hal waktu mulai belajar, tapi disiplin dalam segala hal, seperti mengerjakan pekerjaan rumah, mengerjakan tugas tepat waktu, mengerjakan soal latihan ujian dengan aturan yang berlaku sampai membagi waktu antara kegiatan belajar di kelas dan kegiatan ektstra di luar kelas.

Menurut Gunarsa (2012), disiplin belajar merupakan ketaatan dan kepatuhan terhadap peraturan tertulis maupun tidak tertulis dalam proses perubahan perilaku yang menetap akibat praktik yang berupa pengalaman mengamati, membaca, menirukan, mencoba sesuatu, mendengarkan, serta mengikuti arahan. Disiplin bagi siswa diartikan lebih khusus tindakan yang bertujuan untuk ketaatan dalam lingkungan sekolah, untuk pembangunan kepribadian yang baik diperlukan lingkungan keluarga yang memiliki sikap disiplin yang baik sehingga siswa setiap harinya akan terlatih untuk bertindak disiplin dan penuh tanggung jawab.

Dengan pemberlakuan disiplin, terutama pada bidang belajar, siswa beradaptasi dengan lingkungan dan pola belajar yang baik sehingga muncul keseimbangan diri dalam hubungan dengan orang lain maupun dalam diri siswa. Namun, terdapat beberapa jurnal penelitian yang penulis temui dan pelajari, bahwa masih banyak siswa yang kurang disiplin dalam belajar maupun mematuhi tata tertib di sekolah, seperti:

Berdasarkan hasil penelitian yang dilakukan oleh Marijani (2015:9) sejumlah 34 siswa, telah didapatkan hasil 3 siswa (9\%) memiliki kedisiplinan tata tertib tinggi, 11 siswa (32\%) memiliki kedisiplinan tata tertib sedang dan 20 siswa (59\%) memiliki kedisiplinan tata tertib kurang. Berdasarkan hasil penelitian tersebut dapat disimpulkan bahwa siswa kelas IX TulungAgung Jawa Timur memiliki kedisiplinan tata tertib rendah.

Hasil Penelitian yang dilakukan oleh Siska Yuliantika (2017:8) yang berjudul Analisis Faktor-Faktor Yang Mempengaruhi Disiplin Belajar Siswa Kelas X, XI, XII di SMA Bhakti Yasa Singaraja tahun ajaran 2016/2017. Menunjukan bahwa (1) faktor-faktor yang mempengaruhi disiplin belajar siswa kelas X, XI, XII di SMA Bhakti Yasa Singaraja tahun ajaran 2016/2017 adalah, (a) keadaan fisik dengan nilai varian sebesar $12,662 \%$ (b) faktor keadaan psikis 
dengan nilai varian sebesar 23,782\%, (c) faktor dengan nilai varian $16,540 \%$, (d) faktor penerapan tata tertib sekolah dengan nilai varian $38,498 \%$, (e) dan faktor kondisi lingkungan masyarakat dengan nilai varian $8,558 \%$. (2) Faktor yang paling dominan mempengaruhi disiplin belajar siswa kelas X, XI, dan XII di SMA Bhakti Yasa Singaraja tahun ajaran 2016/2017 adalah penerapan tata tertib sekolah dengan nilai varimax rotation sebesar $38,498 \%$, dan faktor keadaan psikis dengan nilai varimax rotation $23,782 \%$.

Sejalan dengan hasil analisis daftar cek masalah (DCM) dalam satu angkatan yaitu pada kelas X TKJ SMK Larendra pada 6 Juni 2017 diperoleh hasil rata-ratanya pada bidang belajar diperoleh data yaitu siswa belajar tidak teratur waktunya yaitu sebesar, 48,3\%,(29 siswa) siswa belajar hanya waktu malam hari yaitu sebesar $38,3 \%(23$ siswa), siswa sering merasa malas belajar yaitu sebesar 27,8\%(12 siswa), siswa tidak dapat menerapkan cara belajar yang baik yaitu sebesar 15,0\%(9 siswa), siswa sering menyalin PR teman yaitu sebesar 10,0\%(6 siswa), kalau belajar siswa sering mengantuk yaitu sebesar 48,3\%(29 siswa).

Berdasarkan dari hasil wawancara dengan guru Bimbingan dan Konseling SMK Larenda Brebes, ternyata sebagian siswa belum bisa melaksanakan disiplin di sekolah. Hal ini ditunjukan dengan masalah sering tidak masuk tanpa ijin, berpakaian kurang rapi, dan atribut sekolah yang di gunakan tidak lengkap. Hal tersebut didasarkan karena kurangnya kesadaran siswa dalam mengikuti dan mentaati tata tertib di sekolah. Serta kurangnya pemahaman siswa dalam memahami disiplin di sekolah.

Berdasarkan observasi yang dilakukan pada tanggal 5 Juni 2017 menemukan perilaku siswa yang sering terlambat masuk sekolah, siswa sering membolos pada jam kegiatan belajar mengajar, dan gaduh pada saat jam pelajaran membuat pembelajaran terganggu, adapun siswa yang juga sering menyalin pekerjaan rumah temanya untuk dijadikan tugasnya serta ada beberapa siswa yang jarang masuk sekolah.

Dalam kerangka pembangunan dan kemajuan bangsa, disiplin sangat penting. Kemajuan pembangunan, martabat dan kesejahteraan bangsa tercapai karena warga masyarakatnya mempunyai disiplin yang baik. Manusia memerlukan disiplin dalam hidupnya di mana pun berada. Apabila manusia mengabaikan disiplin, akan menghadapi banyak masalah dalam kehidupan sehari-hari. Oleh karena itu, perilaku hidupnya tidak sesuai dengan peraturan yang berlaku di tempat manusia berada dan yang menjadi harapan (Tu'u, 2004: 3435).

Disiplin belajar dapat menciptakan semangat menghargai waktu sehingga tidak banyak waktu yang terbuang dengan percuma, dengan melakukan disiplin belajar juga dapat membuat persiapan yang lebih matang dalam berbagai hal, terutama hal yang membutuhkan banyak persiapan seperti berangkat sekolah, mengikuti ujian, mengikuti seleksi kerja. Di jaman yang sudah modern waktu menjadi salah satu hal yang sangat di perhatikan dan di perhitungkan karena berkaitan dengan tingkat produktifitas yang akan di capai oleh karena itu sikap disiplin belajar sudah di latih sejak saat bangku sekolah, sehingga nantinya siswa akan terbiasa dengan sikap disiplin dan mampu berkompetisi dengan masyarakat lain

Berdasar pada latar belakang, maka peneliti bermaksud mengkaji judul: "Faktor Disiplin Belajar pada Siswa Kelas X SMK Larendra Brebes". Berdasar uraian di atas, maka peneliti ingin meneliti mengenai faktor disiplin belajar siswa di sekolah menggunakan penelitian kualitatif. Metode Kualitatif (Sugiyono, (2013:15) adalah metode penelitian yang berlandaskan pada filsafat postpositivisme, digunakan untuk meneliti pada kondisi obyek yang alamiah, dimana peneliti adalah sebagai instrumen kunci. Metode penelitian kualitatif sering disebut penelitian naturalistic karena penelitiannya dilakukan pada kondisi alamiah. Metode kualitatif digunakan untuk mendapatkan data yang mendalam, suatu data yang mengandung makna yang sebenarnya. 


\section{Metode}

Dalam penelitian ini menggunakan pendekatan penelitian kualitatif. Menurut Sugiyono, (2013: 90). Menyebutkan metode kualitatif adalah metode penelitian yang berlandaskan pada filsafat pospositivisme, digunakan untuk meneliti pada kondisi obyek yang alamiah, (sebagai lawannya adalah eksperimen) dimana penelitian ini adalah sebagai instrumen kunci, teknik pengumpulan data dilakukan secara penelitian kualitatif lebih menekankan makna dari pada generalisasi.

Penelitian ini dilaksanakan untuk mengungkap analisis faktor-faktor kedisiplinan belajar siswa. Untuk memperoleh jawaban tersebut penulis melakukan pengkajian secara mendalam tentang masalah tersebut. Pendekatan yang diterapkan adalah studi kasus. Studi kasus yaitu suatu proses pengumpulan data dan informasi secara mendalam, mendetail, intensif, holistik dan sistematis tentang orang, kejadian, dan menyertakan berbagai sumber informasi (Yusuf, 2014: 339). Penelitian studi kasus yang mendalam melalui observasi, wawancara dan dokumentasi.

Analisis data adalah proses mengorganisasikan dan mengurutkan data ke dalam pola, kategori, dan satuan uraian dasar sehingga dapat ditemukan tema dan dapat dirumuskan hipotesis kerja seperti yang didasarkan oleh data. Miles dan Huberman (dalam Sugiyono, 2017:246) menegaskan, bahwa dalam penelitian kualitatif data yang terkumpul melalui berbagai teknik pengumpulan data yang berbeda-beda, seperti interview, observasi, kutipan, dan sari dari dokumen, catatan-catatan melalui tape; terlihat lebih banyak berupa kata-kata daripada angka. Oleh karena itu, data tersebut harus "diproses" dan dianalisis sebelum dapat digunakan. Aktivitas dalam analisis data dilakukan secara interaktif dan berlangsung secara terus menerus sampai tuntas, sehinga datanya sudah jenuh. Aktivitas dalam analisis data, yaitu data reduction, data display, dan conclusion drawing/verification.

\section{Hasil dan Pembahasan}

Dari temuan hasil penelitian yang dilakukan oleh peneliti, diperoleh hasil yang didapat mengenai faktor yang mempengaruhi prilaku agresif siswa SMK Larenda Brebes adalah sebagai berikut:

Faktor-faktor yang mempengaruhi mengapa siswa banyak yang tidak bisa menerapkan sikap disiplin dalam bidang belajar sebagai berikut:

a. Faktor Intern (dari diri sendiri)

Kurang motivasi, malas, siswa tidak memiliki minat belajar yang tinggi dan siswa tidak bisa menerapkan cara belajar yang baik, pengertian dari kedisiplinan itu sendiri dapat diartikan sebagai kepatuhan atau ketaatan terhadap peraturan yang berlaku. Sedangkan arti dari belajar adalah kegiatan yang dilakukan oleh siswa untuk mengetahui sesuatu yang belum diketahui.

b. Faktor Extern (dari luar)

Orang tua yang kurang memberikan dukungan, guru yang kurang memerikan motivasi kepada siswa, teman sebaya atau lingkungan yang sangat mempengaruhi kedisiplinan siswa. Peran guru BK yang kurang memberikan motivasi belajar kepada siswa dengan memberikan layanan bimbingan konseling.

\section{Simpulan dan Saran}

Berdasarkan hasil penelitian dan pembahasan, maka penulis dapat menarik kesimpulan bahwa ada beberapa faktor yang mempengaruhi kedisiplinan belajar siswa yaitu faktor individu atau siswa, lingkungan, guru, keluarga dan fasilitas dari beberapa faktor tersebut membuat siswa memiliki kedisiplinan belajar. .Faktor-faktor yang mempengaruhi kedisiplinan belajar siswa yang paling dominan adalah faktor individu dan faktor lingkungan. Menjadi tanggung jawab bersama antar pihak memberi pengawasan dalam kegiatan siswa terutama belajar agar 
siswa lebih bijak dalam pengelolaan waktu belajar sehingga siswa memiliki kedisiplinan belajar yang tinggi.

Saran dari peeliti yaitu: Siswa sebaiknya perlu meningkatkan kesadaran diri akan pentingnya kedisiplinan belajar untuk masa depannya. Siswa perlu dukungan dari lingkungan sekitar yang mampu membuat siswa disiplin dalam belajar. Perlunya keikutsertaan orangtua dalam memantau dan memotivasi anaknya agar kesadaran belajar serta ketekunan menghadapi tugas dan kedisiplinan belajarnynya menjadi meningkat. Pemberian semangat belajar, motivasi belajar harus selalu diberikan setiap pembelajaran dilakukan. Hal ini agar motivasi belajar siswa.

\section{Daftar Pustaka}

Abu ahmadi dan Widodo Supriyono. 2008. Psikologi Belajar. Jakarta: Rineka Cipta.

Amri, Sofan, dkk. 2011. Implementasi Pendidikan Karakter Dalam Pembelajaran. Jakarta. Prestasi Pustaka.

Djamarah, Syaiful Bahri. 2008. Rahasia Sukses Belajar. Jakarta : Rinekta Cipta.

Ekosiswoyo Rasdi \& Rahman. 2002. Manajemen kelas sesuai dengan kurikulum D-II PGSD. Semarang: IKIP Semarang Press.

Elly, Rosma. 2016. Hubungan Kedisiplinan terhadap Hasil Belajar Siswa Kelas V di SD Negeri 10 Banda Aceh. Jurnal Pesona Dasar Vol. 3 No. 4 Hal. 43-53. Tersedia Pada : http://www.jurnal.unsyiah.ac.id/PEAR/article/download/7540/6207.

Halsey, Wiliam. 1979. MacMillan Dictionary. New York : MacMillan Publishing

Johan, Ria Susanti. 2014. Peran Motivasi dan Disiplin dalam Menunjang Prestasi Belajar Peserta Didik pada Bidang Studi IPS. Faktor Jurnal IImiah Kependidikan Vol. 1 No. 3 Hal. 275-286. Tersedia Pada

https://journal.Ippmunindra.ac.id/index.php/Faktor/article/view/364.

Lewis, Ramon. 2004. Dilema Kedisiplinan. Jakarta: PT Grasindo Anggota Ikapi.

Marijani. 2015. "Peningkatan Kedisiplinan Tata Tertib Melalui Layanan Bimbingan Kelompok dengan Teknik Bermain Peran di SMP Negeri 5 Tulungagung." Jurnal Penelitian Tindakan Bimbingan Konseling, Vol: 1, No: 2 h.11http://journal.unnes.ac.id (diakses pada hari Jumat 5 Mei 2017)

Prijodarminto, Soegeng. 1994. Disiplin, Kiat Menuju Sukses. Jakarta : Abadi

Rachman, Maman. 1999. Manajamen Kelas. Jakarta : Depdiknas, Proyek Pendidikan Guru SD.

Rumia. 2015. Analisis Tingkat Kedisiplinan Peserta didik Sebelum dan Sesudah Prakerin di SMK Negeri 3 Tarakan. Jurnal Kebijakan dan Pengembangan Pendidikan Vol. 3, No. 1, Hal.117-125. Tersedia Pada http://ejournal.umm.ac.id/index.php/jmkpp/article/view/2209.

Slameto. 2002. Belajar dan Faktor-faktor yang mempengaruhinya. Jakarta: Rineka Cipta.

Siska, 2017. "Analisis faktor Yang Mempengaruhi Disiplin Belajar Siswa Kelas X, XI, Dan XII, di SMA Bhakti Yasa Singraja." Jurnal Pendidikan Ekonomi, Vol: 9 No: 1 h. 8. http://ejournal.undiksha.ac.id (diakses pada hari rabu 3 mei 2017) 
2010. Metode Penelitian Pendidikan. Bandung : Alfabeta.

Sugeng Haryono. 2016. Pengaruh Kedisiplinan Siswa dan Motivasi Belajar terhadap Prestasi Belajar Siswa pada Mata Pelajaran Ekonomi. Faktor Jurnal IImiah Kependidikan Vol. 3 No. 3 Hal 261-274. Tersedia Pada: http://journal.Ippmunindra.ac.id/index.php/Faktor/article/download/939/874.

Sugiyono. 2013. Metode Penelitian Kuantitatif Kualitatif dan $R n D$. Bandung: Alabeta, CV.

Tuu, Tulus. 2004. Peran Disiplin pada Perilaku dan Prestasi Siswa. Jakarta : PT Grasindo.

Tohirin. 2012. Metode penelitian kuantitatif, kualitatif, dan R\&D. Bandung; Alfabeta.

Undang- Undang Republik Indonesia Nomor 20 Tahun 2003 Tentang Sistem Pendidikan Nasional

Wantah, Maria J. 2005. Pengembangan Disiplin dan Pembentukan Moral Pada Anak Usia Dini. Jakarta: Depdiknas.

Yusuf, A. Muri. 2014. Metode Penelitian: Kuantitatif, Kualitatif, dan Penelitian gabungan. Jakarta: Prenadamedia group.

Yulita Rintyastini \& Suzy Yulia Charlotte S. 2006. Bimbingan dan Konseling SMP kelas VII. Jakarta: Erlangga. 